\title{
RISING TIDES AND RETIREMENT: \\ THE AGGREGATE AND DISTRIBUTIONAL EFFECTS OF DIFFERENTIAL WAGE GROWTH ON SOCIAL SECURITY
}

\author{
Melissa M. Favreault*
}

CRR WP 2009-7

Released: March 2009

Draft Submitted: January 2009

\author{
Center for Retirement Research at Boston College \\ Hovey House \\ 140 Commonwealth Avenue \\ Chestnut Hill, MA 02467
}

Tel: 617-552-1762 Fax: 617-552-0191

* Melissa M. Favreault is a senior research associate at the Urban Institute. The research reported herein was pursuant to a grant from the U.S. Social Security Administration (SSA) funded as part of the Retirement Research Consortium (RRC). The findings and conclusions expressed are solely those of the author and do not represent the views of SSA, any agency of the Federal Government, the RRC, the Urban Institute, its Board, or sponsors. I thank Sheila R. Zedlewski for helpful comments.

(C) 2009, by Melissa M. Favreault. All rights reserved. Short sections of text, not to exceed two paragraphs, may be quoted without explicit permission provided that full credit, including $\odot$ notice, is given to the source. 


\title{
About the Center for Retirement Research
}

The Center for Retirement Research at Boston College, part of a consortium that includes parallel centers at the University of Michigan and the National Bureau of Economic Research, was established in 1998 through a grant from the Social Security Administration. The Center's mission is to produce first-class research and forge a strong link between the academic community and decision makers in the public and private sectors around an issue of critical importance to the nation's future. To achieve this mission, the Center sponsors a wide variety of research projects, transmits new findings to a broad audience, trains new scholars, and broadens access to valuable data sources.

\author{
Center for Retirement Research at Boston College \\ Hovey House \\ 140 Commonwealth Avenue \\ Chestnut Hill, MA 02467 \\ phone: 617-552-1762 fax: 617-552-0191 \\ e-mail: crr@bc.edu \\ www.bc.edu/crr
}

Affiliated Institutions:

The Brookings Institution

Massachusetts Institute of Technology

Syracuse University

Urban Institute 


\begin{abstract}
Recent growth in wage inequality has important implications for Social Security solvency and the distribution of benefits. Because only earnings below the taxable maximum are subject to Social Security payroll taxes, wage growth that is concentrated among very high earners will generate lower tax receipts than wage growth that is more evenly distributed. The progressivity of the Social Security benefit formula increases benefit payouts when the share of workers with low wages grows. This study uses a dynamic microsimulation model to examine the aggregate and distributional consequences of alternative scenarios about the distribution of future wage growth among workers. We find fairly marked changes in projected Social Security benefit distributions, poverty, and long-term financing status with relatively modest changes in assumptions about wage differentials.
\end{abstract}




\section{Introduction}

How do different patterns of wage growth affect Social Security solvency and the distribution of benefits? Recent wage growth has been concentrated among high earners (Kopczuk et al. 2007). Because only earnings below the taxable maximum (set at $\$ 106,800$ per year in 2009, and indexed to account for wage inflation) are subject to Social Security payroll taxes, a continuation of this trend raises the concern that tax receipts may be lower than anticipated. Wage growth that is concentrated among very high earners would generate lower tax receipts than wage growth that is more evenly distributed across the population.

If this earnings growth among the highest wage earners is accompanied by reductions in relative wages for the lowest-wage workers (i.e., a scenario in which the "rich get richer" and leave everyone else behind), Social Security's progressive benefit formula could compound this financing issue by generating relatively large payouts (compared to taxes paid) for low-wage workers. The relationship between wage levels and Old-Age, Survivors, and Disability Insurance (OASDI) benefits is complex because of the placement of the formula brackets, the availability of special benefits to spouses and survivors with limited or no work histories, and other program provisions. ${ }^{1}$ Funding pressures would be exacerbated if recent trends increase the share of low-wage workers relative to middle-wage workers.

These varied tax and benefit effects could play out in interesting ways, with important implications for Social Security reform (see the Appendix for further discussion). This study examines the aggregate and distributional consequences of alternative scenarios about the

\footnotetext{
${ }^{1}$ These include, for example, the 10-year "vesting" rule for retired worker benefits (i.e., the requirement for 40 covered quarters) and the fact that benefits are based on average indexed monthly earnings (AIME), which relies only on the top 35 years of earnings (rather than all earnings years). For those reaching age 62, becoming disabled, or dying in 2009, Social Security replaces 90 percent of average AIME through the first bend point of $\$ 711,32$ percent for earnings between $\$ 744$ and the second bend point of $\$ 4,483$, and 15 percent of earnings for earnings above this second bend point. For details on AIME and Primary Insurance Amount (PIA) computations, see Social Security Administration (2008).
} 
distribution of future wages among workers. It uses a dynamic microsimulation model of the U.S. population to compare the distribution of future Social Security benefits and retirement incomes under the assumption that wages grow so that the wage distribution roughly maintains its current shape, an alternative wage growth assumption that favors high-wage workers, and a second alternative that favors low- to moderate-wage workers. These alternatives reflect a narrow_but certainly plausible_range of possibilities. The project also assesses how different wage distribution assumptions affect system solvency.

\section{Background, contribution to the literature, and policy relevance}

Income inequality has received increasing attention in recent years. President Barack

Obama mentioned the issue during his campaign, and pledged to create a task force on bolstering the economic security of the middle class early in his presidency (Freking 2008). Before the presidential campaign was in full swing, the Federal Reserve Chairman (Bernanke 2007), former Secretary of the Treasury (Paulson 2006), and even former President (Bush 2007) all addressed inequality in high-profile public statements. Other political leaders and members of the business community, including some of the wealthiest individuals and investment banks, urged attention to the matter (see, for example, Gross 2007). While these different sources surely had different concerns about inequality and varied motivations for raising the issue, the fact that activity was widespread across such a wide spectrum suggests that public interest and concern about recent trends in income distribution has been acute.

Figure 1 shows how earnings inequality has affected one important dimension of the Social Security program: the fraction of total earnings in Social-Security covered employment that are subject to OASDI payroll tax. As the highest earners' wages grow faster than wages for all earners at large (in the technical terminology, as the fraction of earnings in covered 
employment that are above the taxable maximum increases), this ratio falls. ${ }^{2}$ In 1983 , this ratio was about 90 percent. More recently, it has ranged from about 83 to 86 percent, and, according to the latest data (for 2006), appeared to be on the low end of this range, about 83.6 percent. Regardless of the precise level today, the ratio has clearly trended downward over the past two and a half decades. Some propose addressing this shift by altering current law on payroll tax contributions, for example by imposing a surtax on earnings far above the cap or restoring the taxable maximum to the level where it covers 90 percent of covered earnings. ${ }^{3}$ This latter change would be approximately equivalent to raising the taxable maximum to \$164,100 in 2006 (Wade, Skirvin, and Piet 2005) and \$213,000 this year (correspondence from Wade, 2009). ${ }^{4}$

Figure 1. Percentage of Total Earnings in OASDI-Covered Employment Reported Taxable (Combined Wage and Salary and Self-Employed Workers)

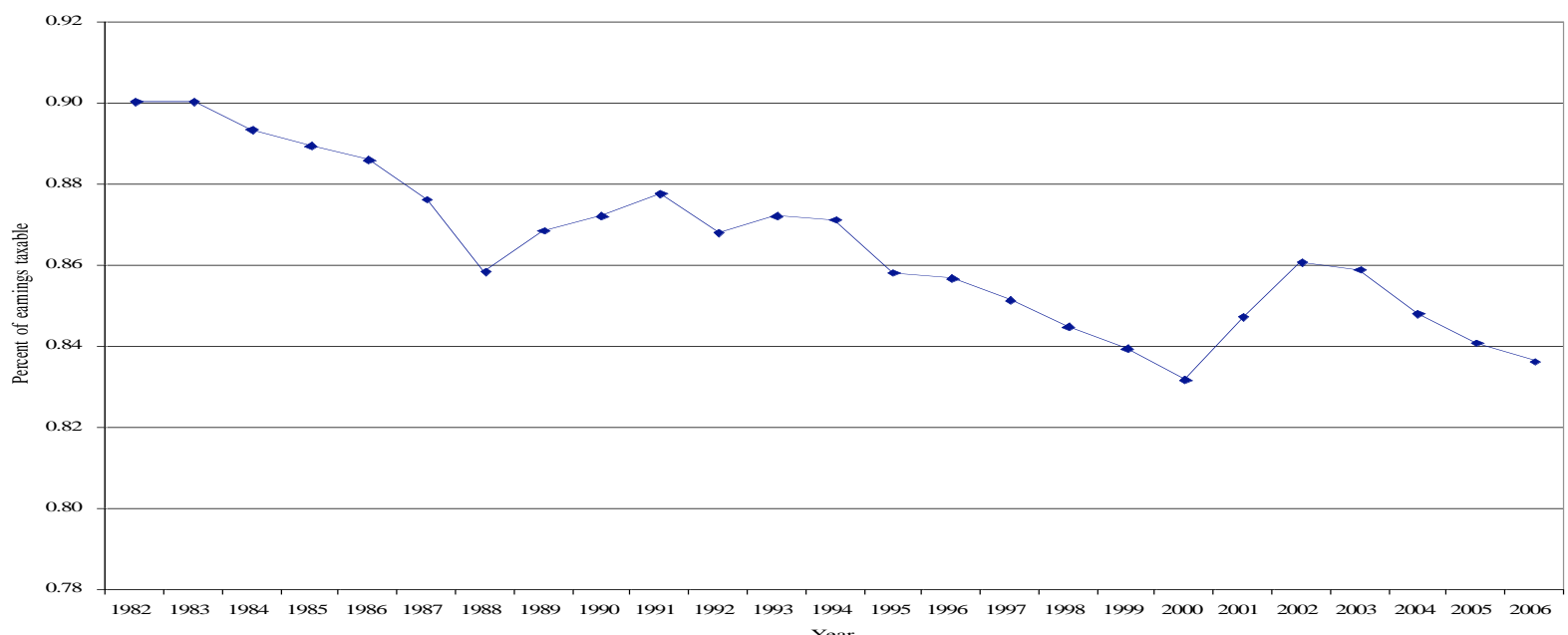

Source: Social Security Administration (2008), Table 4.B2

Notes: Vertical scale does not start at zero. Data for 2003-2006 are preliminary.

\footnotetext{
${ }^{2}$ When thinking about the fraction of wages in the economy that are subject to the Social Security payroll tax, another nuance is that not all jobs are covered by Social Security. Certain workers, predominantly state and local employees, are not covered by the program. These workers made up about 4.0 percent of the civilian labor force in 2002 (Committee on Ways and Means 2004).

${ }^{3}$ Several proposed reform packages have included an increase in Social Security's wage and benefit base (see, for example, Diamond and Orszag 2004 and Liebman, MacGuineas, and Samwick 2005). President Barack Obama has proposed applying the payroll tax to earnings above \$250,000 (Obama for America 2008, Babington 2008).

${ }^{4}$ This estimate, based on assumptions of the 2008 Trustees report, is likely to be revised when new data reflecting the current economic downturn become available.
} 
Given the cumulative nature of retirement preparation, it is important to understand how changes in wage growth like this accumulate over workers' lifetimes. On average, real wage growth — that is, the difference between changes in wages and prices after accounting for inflation-for U.S. workers has averaged just over 1 percent per year. There have been difficult periods, for example in the 1970s, when wages failed to keep up with price inflation on average (see the flat and declining segment from 1972 to 1982 in Figure 2). There have also been boom periods, for example in the late 1990s, when wages grew faster than prices (see the steep slope for 1995 to 2000 in Figure 2). Social Security's Trustees project that in the long run, wages will continue to grow faster than prices by 1.1 percent (OASDI Board of Trustees 2008). These projections, made before the severity of the current economic situation was known, are likely to be revised for the near term years when they are updated later in 2009.

Figure 2. Cumulative Real Wage Growth: Historical and Projected, 1951-2021

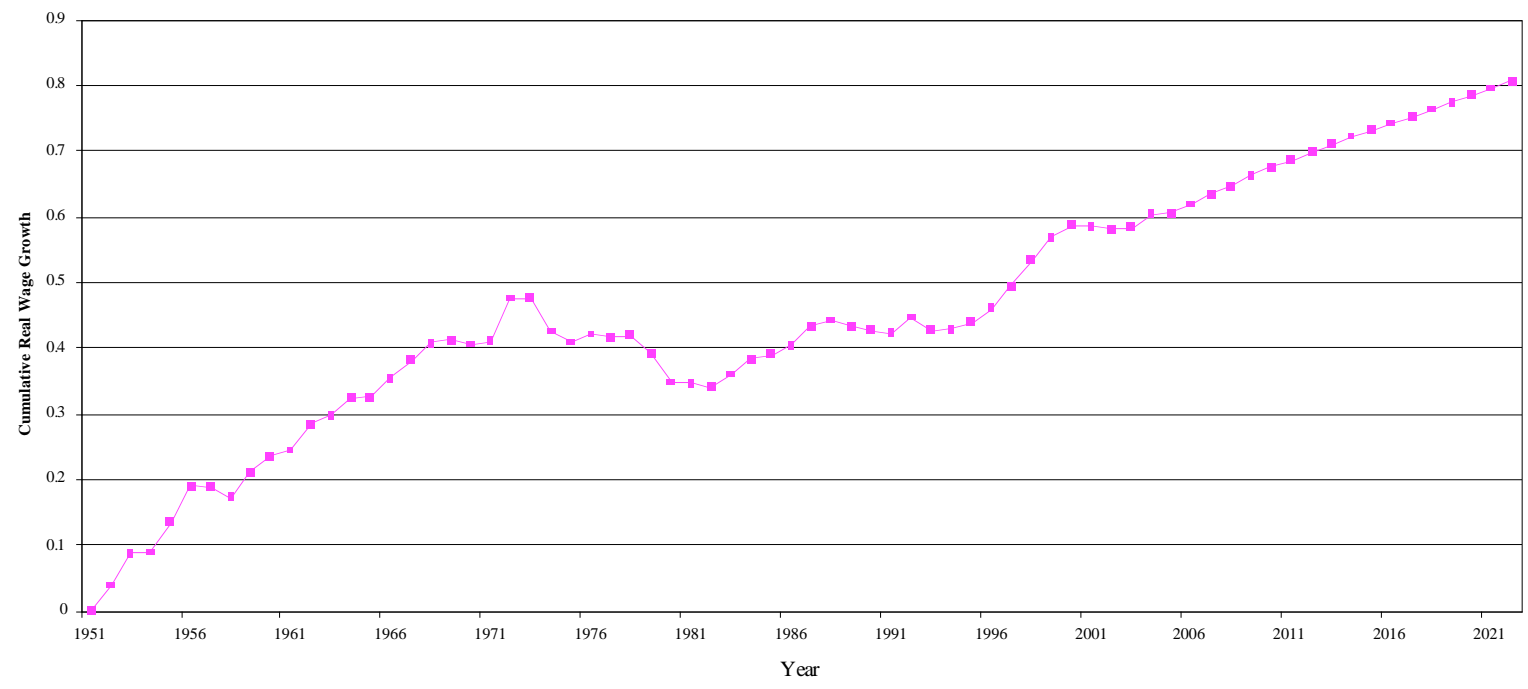

Source: Author's calculations from OASDI Board of Trustees (2008).

Notes: Real wage growth is defined as the difference between the change in the average wage index and the change in the Consumer Price Index for Urban Wage Earners and Clerical Workers (CPI-W). 
Because initial Social Security benefits are indexed to wages, we expect real benefits from the program to increase over time, all else equal. ${ }^{5}$ And faster wage growth (i.e., a higher real wage differential) could extend the system's solvency. ${ }^{6}$ As many authors have observed (for example, Penner 2008), the benefits of wage growth for the Social Security system's longterm financing are limited: the greater payroll tax revenues are eventually partially offset by larger benefit payments (with a lag).

While overall U.S. wages have grown over time, clearly some people's wages grow faster than others'. Over recent decades, the wages of better educated workers (e.g., those with a college education) have grown more quickly than those of less educated workers. Figure 3 summarizes information from a recent Bureau of Labor Statistics (2008) study based on data from the National Longitudinal Survey of Youth, which followed a group of young Americans born between 1957 and 1964 for over 25 years.

Figure 3. Real Growth in Annual Wages by Education and Age Group, 1978-2006

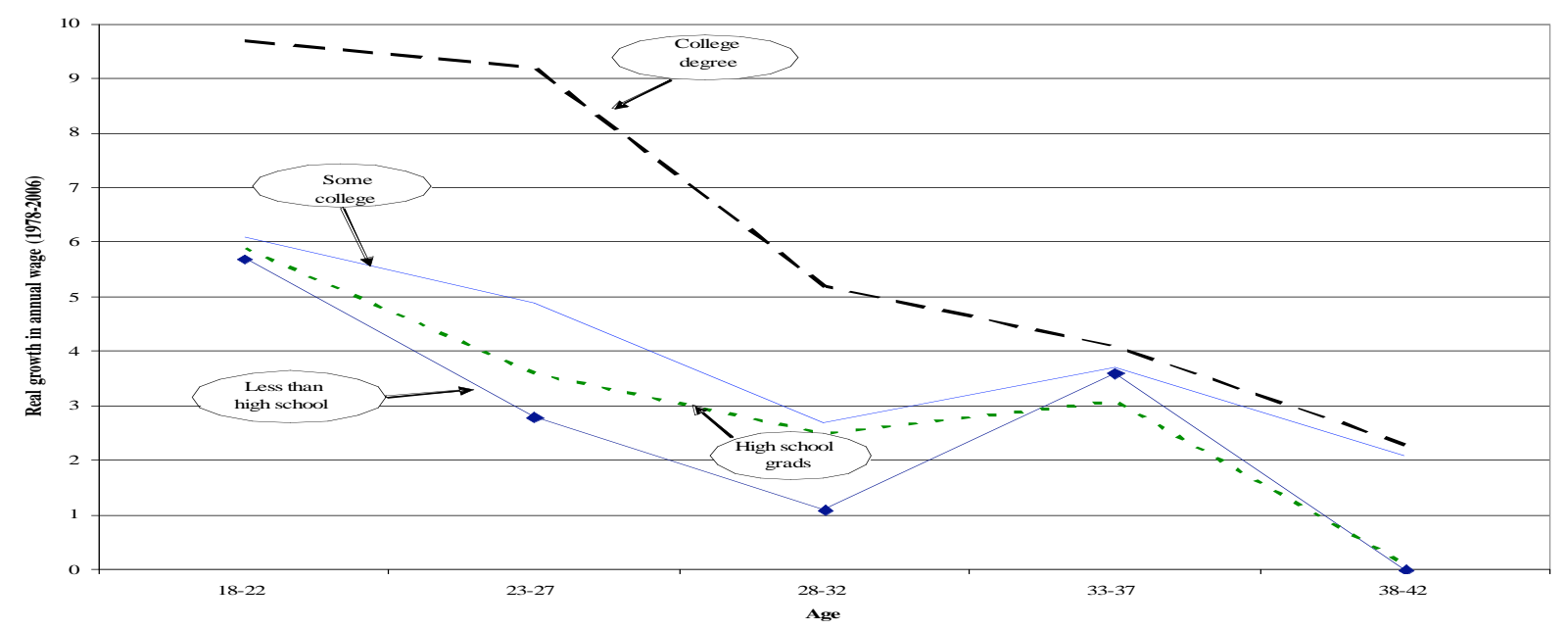

Source: Bureau of Labor Statistics (2008), Table 5.

\footnotetext{
${ }^{5}$ After initial benefits are assigned, they grow with prices. For members of some birth cohorts, normal retirement age increases partially offset the growth (in price adjusted terms) of benefits.

${ }^{6}$ According to the OASDI Trustees Report, for example, an extra 0.5 percentage points of real wage growth would add seven years to the system's insolvency date (Board of Trustees 2008).
} 
We see that, within every age range, those with a college degree experienced faster real wage growth than their less educated counterparts. At the oldest age range (ages 38 to 42 ), those with a high school degree or less experienced virtually no wage growth (i.e., their wages kept up with inflation, but did not increase beyond that). At all ages, those with some college occupy an intermediate position between the college graduates and those with high school or less.

Literature that tracks patterns like this in earnings, income, and wealth inequality is vast and growing. Much work has focused on estimating these patterns well, given the difficulty of accurately measuring earnings and income over time (see, for example, Kopczuk et al. 2006 and Piketty and Saez 2003). Particularly noteworthy is a finding of highly concentrated earnings and income growth not just among the better educated (as indicated in Figure 3), but especially rapid growth among the very highest earners (a small subset of individuals, typically among the better educated). Some describe this, in combination with stagnation for earners at the bottom, as a "polarization" of the U.S. wage distribution (Autor et al. 2006, Goldin and Katz 2007).

Efforts to explain the reasons for changing wage differentials and this polarization have spurred another branch of the literature (for a review, see Machin 2008). Much of this literature emphasizes skill-biased technological change (see, for example, Autor et al. 2008) and outsourcing. Other authors highlight the role of institutions, like unionization levels and union negotiating power, the minimum wage, and tax policy (see, for example, Levy and Temin 2007). Related work tries to explain how high poverty rates can persist in the U.S. despite steady economic growth, and points to differential wage growth as a primary explanation (see, for example, Freeman 2001).

Little work has considered the cumulative impacts of differential wage growth, and how they play into retirement preparedness and fiscal burdens. Smith (2003) provides an earlier 
analysis of the possible effects of the recent rise in wage inequality on retirement preparedness, and points to Social Security's role in mitigating the effects of rising wage inequality on retirement incomes. This paper builds on the Smith study, taking into account more recent data (covering the last several years when wage growth differentials were especially pronounced), and tests the sensitivity of different wage growth assumptions, rather than focusing on a "best guess" scenario.

Pattison (2003) authored another study with some similarities to this project. His research considered wage growth differentials by gender, examining the implications for spouse and survivor benefits, wages, OASDI solvency, and even second-order effects on the average wage (which is used for Social Security benefit indexing, and thus has important impacts on benefit levels). He found that increases in women's payroll taxes more than offset any associated benefit increases (to the benefit of the OASDI Trust Fund), and that second-order effects on benefits that operated through changes to the average wage (resulting from women's work) were also important.

The Social Security Advisory Board's Technical Panel on Assumptions and Methods (2007) recommends additional research on trends in wage dispersion on Social Security financing. They identify a need for a stronger basis for projecting shares of total wages above and below the taxable maximum. The panel also calls for sensitivity analyses of this issue. So expert opinion suggests that this important question is worthy of further study.

\section{Project methods}

We begin with the assumptions in the 2008 Social Security Trustees Report as a baseline (OASDI Board of Trustees 2008). Under their intermediate forecast, the Trustees assume that the portion of covered earnings that will be taxable (that is, at or below the wage base) will 
decline from 83.3 percent in 2006 to 82.9 percent in 2017 . They attribute the decline to the relative increase in wages for high-wage earners and the change in the age-sex distribution of the workforce (as the baby boomer generation moves to ages when they have higher relative earnings). After 2017, the Trustees assume that the ratio of taxable to covered earnings will be about constant. ${ }^{7}$

We contrast this "best guess" projection with a second scenario that assumes a steeper decline in covered taxable earnings_-more closely matching the rate observed over the recent past - that lasts throughout the projection period. The third scenario assumes that this trend reverses (with wage growth skewed toward lower-wage workers). In all cases, we assume that employment rates and the average earnings of workers stay the same (at the levels in the Trustees intermediate assumptions) — only the skewness in wages changes. The three scenarios bracket a relatively narrow range of possibilities but nonetheless can demonstrate the sensitivity of revenues, benefits, and net payout to plausible earnings differentials.

The project uses DYNASIM3, the Urban Institute's dynamic microanalytic simulation model. DYNASIM3 has a starting population based on the 1990 to 1993 panels of Survey of Income and Program Participation (SIPP), and forecasts Social Security and other retirement income sources as far as 2082 (see Favreault and Smith 2004 for a description of an earlier version of the model). The model incorporates many of the key assumptions of the 2008 Trustees (for example, about fertility, mortality, and wage growth) in developing its forecasts and can simulate the sensitivity of results to changes in these parameters. The microanalytic equations that age the data were estimated using a wide range of longitudinal data sources.

\footnotetext{
${ }^{7}$ See section C, Chapter V of the Social Security Administration Trustees Report (Board of Trustees 2008) for a description of these assumptions.
} 
DYNASIM models employment and earnings using a four-stage process. First, individuals make choices about whether to work or not. Second, people select a number of hours to work, in part based on the wage rate that they expect they can earn. Third, they are assigned a wage rate (estimated using a logarithmic specification to account for the skewness in the distribution). Annual earnings are simply the product of workers' wages and hours. Finally, DYNASIM aligns the average earnings these equations generate to the intermediate assumptions of the Social Security Trustees. ${ }^{8}$

In each of these first three equation stages (employment, hours, and wages), the functions that determine the DYNASIM work outcomes include a wide variety of explanatory variables in order to pick up key demographic and socioeconomic differentials in the processes. The equations also use complex error structures, with temporary and permanent components (including an autoregressive factor). ${ }^{9,10}$

One significant complication for designing the current analyses is determining how to attribute differential wage growth in the alternative scenarios. For example, one possibility is that wage growth at the top of the earnings distribution reflects an increasing premium on education. An alternative is that differential wage growth would not benefit all workers with advanced educational credentials the same way, but rather would be concentrated on a small subset of exceptional individuals who are best able to take advantage of rapid changes in

\footnotetext{
${ }^{8}$ As part of the process of aligning total earnings to average wages, DYNASIM also undertakes a "high-earner" alignment. This is necessary because regression-based simulation methods can have difficulty generating the extreme outliers that can have great influence on the average earnings, even in a sample of DYNASIM's size (starting out at 105,000 and eventually increasing to 177,000 in 2082, with almost 330,000 individuals who are ever alive in the United States at some point in the simulation). The higher earner adjustments affect fewer than a dozen in some early simulation years and a maximum of two dozen cases (in later years of the simulation).

${ }^{9}$ For discussion of error structures in earnings models, see, for example, Lillard and Willis (1978) and Moffitt and Gottschalk (2002).

${ }^{10}$ Such models take into account the fact that some people are more talented or diligent, or employed at better firms, than others who appear extremely similar to them (for example, someone of the same gender, educational level, race, and work experience) - this is a "permanent" difference reflected in the permanent component of the error.
} 
technologies, institutions, or other factors. Each assumption requires a different simulation strategy. ${ }^{11}$

Recent evidence suggests that over the past few decades, both of these factors have contributed to a more skewed earnings distribution, but that the latter trend (especially high returns to a small subset of individuals) has been more prominent (see, for example, Piketty and Saez 2006, Autor et al. 2006, Gordon and Dew-Becker 2007). As a result, our simulations focus on this particular form of skewness. Table 1 presents details of the options we elected to simulate, all of which are assumed to take effect this year (2009).

Table 1. Alternative Wage Growth Assumptions Simulated

\begin{tabular}{lll}
\hline \multicolumn{1}{c}{ Scenario } & $\begin{array}{c}\text { Long-term (post-2040) percent } \\
\text { of earnings in OASDI-covered } \\
\text { employment that are taxable }\end{array}$ & $\begin{array}{c}\text { Implementation } \\
\text { (All take effect in 2009) }\end{array}$ \\
\hline & $\begin{array}{l}\text { Varies around OCACT } \\
\text { assumption of 82.9 percent }\end{array}$ & $\begin{array}{l}\text { "Best guess" coefficients and } \\
\text { error structures }\end{array}$ \\
$\begin{array}{l}\text { Wageline growth (after 2008) } \\
\text { skewed toward high- } \\
\text { earners }\end{array}$ & Varies around 81.7 percent & $\begin{array}{l}\text { Via the permanent component } \\
\text { of error term in ln(wage) } \\
\text { equation for highest 5th of the } \\
\text { top percentile }\end{array}$ \\
$\begin{array}{l}\text { Wage growth (after 2008) } \\
\text { skewed toward low- to } \\
\text { moderate-earners }\end{array}$ & Varies around 84.0 percent & $\begin{array}{l}\text { Via the permanent component } \\
\text { of error term in ln(wage) } \\
\text { equation for lowest half of the } \\
\text { distribution }\end{array}$ \\
\hline
\end{tabular}

A second complication in the research approach is whether (and, if so, how) to build feedback effects into the model when processing these simulations. Increases in wage rates

\footnotetext{
They also take into account the fact that sometimes individuals' work careers are temporarily derailed, for example by a layoff or injury or bad year for one's firm, reflected in the transitory component of the error.

${ }^{11}$ In the first case, one strategy would be to modify the slopes on education and the age-education interaction terms in the model's wage equations to integrate the change into the underlying model. In the second case, integrating the change through the permanent component of the error term in the model's wage equations makes more sense.

${ }^{12}$ We use the term "varies around" because these values are generated by DYNASIM by a large number of equations and algorithms, rather than input as targets, and fluctuate from year to year in response to random variation.
} 
could have additional effects that are relevant to Social Security payroll tax and benefit distributions, overall program costs, and beneficiary poverty. We include certain feedbacks in the analyses, but not others. For example, in the simulation individuals do alter their savings (and thus wealth holdings) as a result of the changes to their earnings. Likewise, individuals may claim Social Security benefits earlier or later because of their new circumstances. The model also includes changes to OASDI entitlement that these new relative earnings or claiming choices generate. For example, if a worker's own and/or spouse's earnings and actuarial reductions now differ, they can convert to new benefit types (for example, from worker to spouse/survivor or the reverse). If one spouse's wages increase markedly, it may change the chances that the second spouse works part time or exits the labor force in the model (see, for example, Blau and Kahn 2007 on trends in cross wage elasticities for women). All sorts of demographic decisions (for example, the choice to marry or have a child) can also respond to changes in modeled earnings.

Changes that these analyses do not integrate include, for example, macro-economic feedbacks. As we do not include second-order effects of this type in the analyses, we recommend cautious interpretation of the results.

When projecting Social Security benefits, the choice of baseline becomes important starting in 2041, the year that the Trustees project the Trust Fund will become insolvent. To bracket the range of possible outcomes, we produce benefit and total income estimates using both scheduled benefits and payable benefits. Our payable estimates assume that benefit reductions (as opposed to some combination of payroll or income tax increases and benefit reductions) would make up the entire Social Security shortfall. ${ }^{13}$

\footnotetext{
${ }^{13}$ When making these adjustments, we use OCACT projections of the combined OASDI Trust fund balance (OASDI Board of Trustees 2008) to adjust benefits both for OASI and DI recipients, rather than adjusting benefits based on the timing of insolvency and financial position of the respective Trust Funds.
} 


\section{Historical data}

Before we examine how Social Security tax and benefit distributions look under the DYNASIM simulations with alternative wage growth assumptions, it is useful to first understand what these distributions look like today. Figure 4 presents the taxable earnings distribution (in $\$ 10,000$ increments) for OASDI-covered workers in 2005, the most recent year for which relatively complete data are published. The median, or point at which half earn more and half earn less, was about \$22,900 in 2005 (Social Security Administration 2008, Table 4.B6). Well over a quarter of earners received less than $\$ 10,000$ in covered earnings. Because the figure's population reflects workers with any covered earnings, it has far more low-earners than would an earnings distribution that was restricted to, say, full-time, full-year workers. About 6 percent of workers in OASDI-covered employment earned the taxable maximum or more.

Figure 4. Annual Earnings of Social Security Covered Workers: 2005

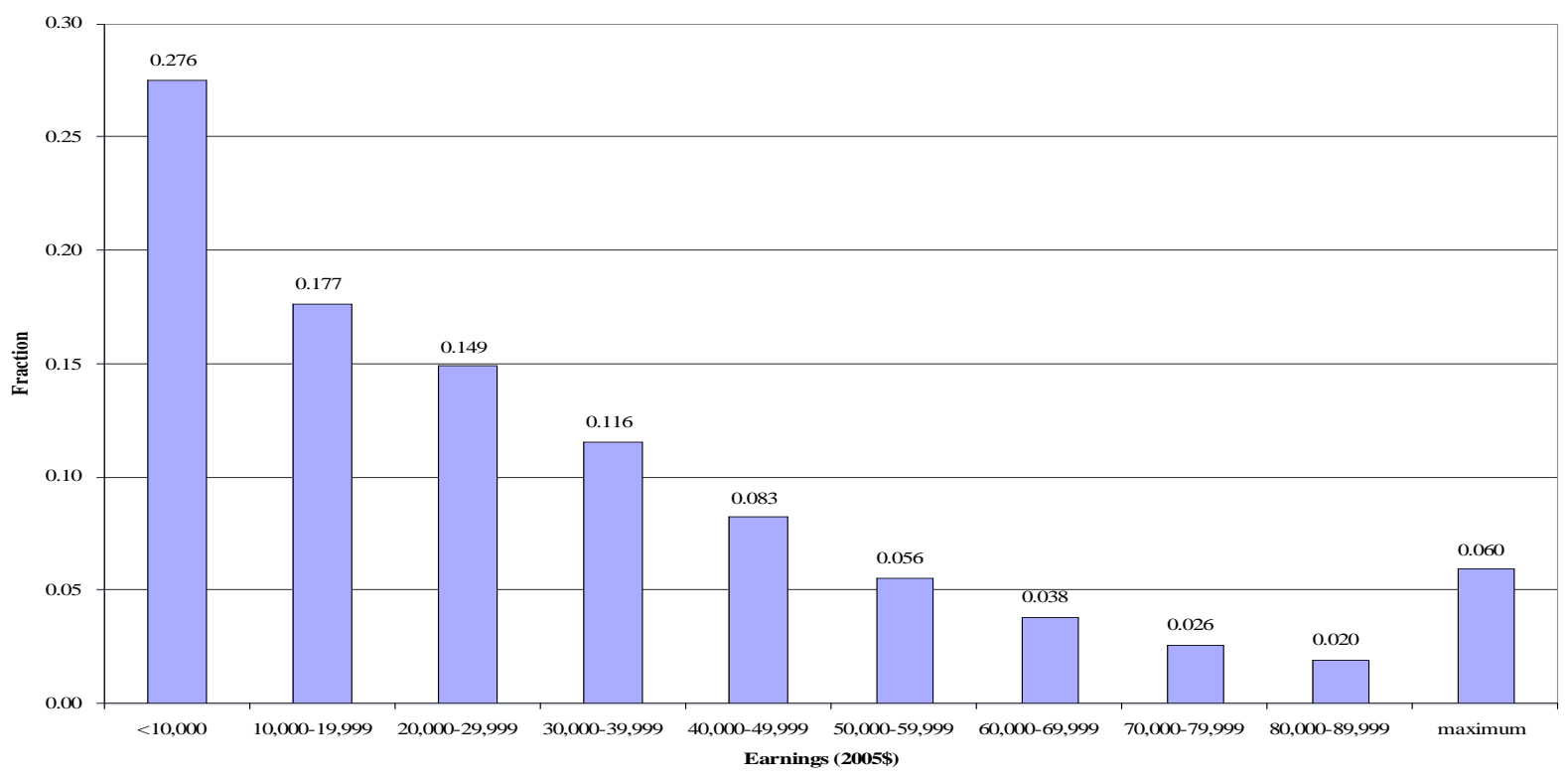

Source: Social Security Administration (2008), Tables 4.B7 and 4.B9.

Notes: Includes both wage and salary and self-employed workers. Data are preliminary. 
Figure 4 depicts the Social Security monthly benefit distribution (in $\$ 50$ increments) for adult individuals with retired worker, disabled worker or aged survivor benefits in $2006 .{ }^{14}$ Together, these groups comprised 93.3 percent of adult Social Security beneficiaries and 96.5 percent of total OASDI benefits paid to adults (Social Security 2008, author's calculations from Table 5.A1). ${ }^{15}$ In both our historical and projection analyses, we focus on adult Social Security benefits. $^{16}$

Figure 5. Social Security Monthly Benefit Distribution: Retired and Disabled Workers and non-Disabled Widow(er)s, December 2006

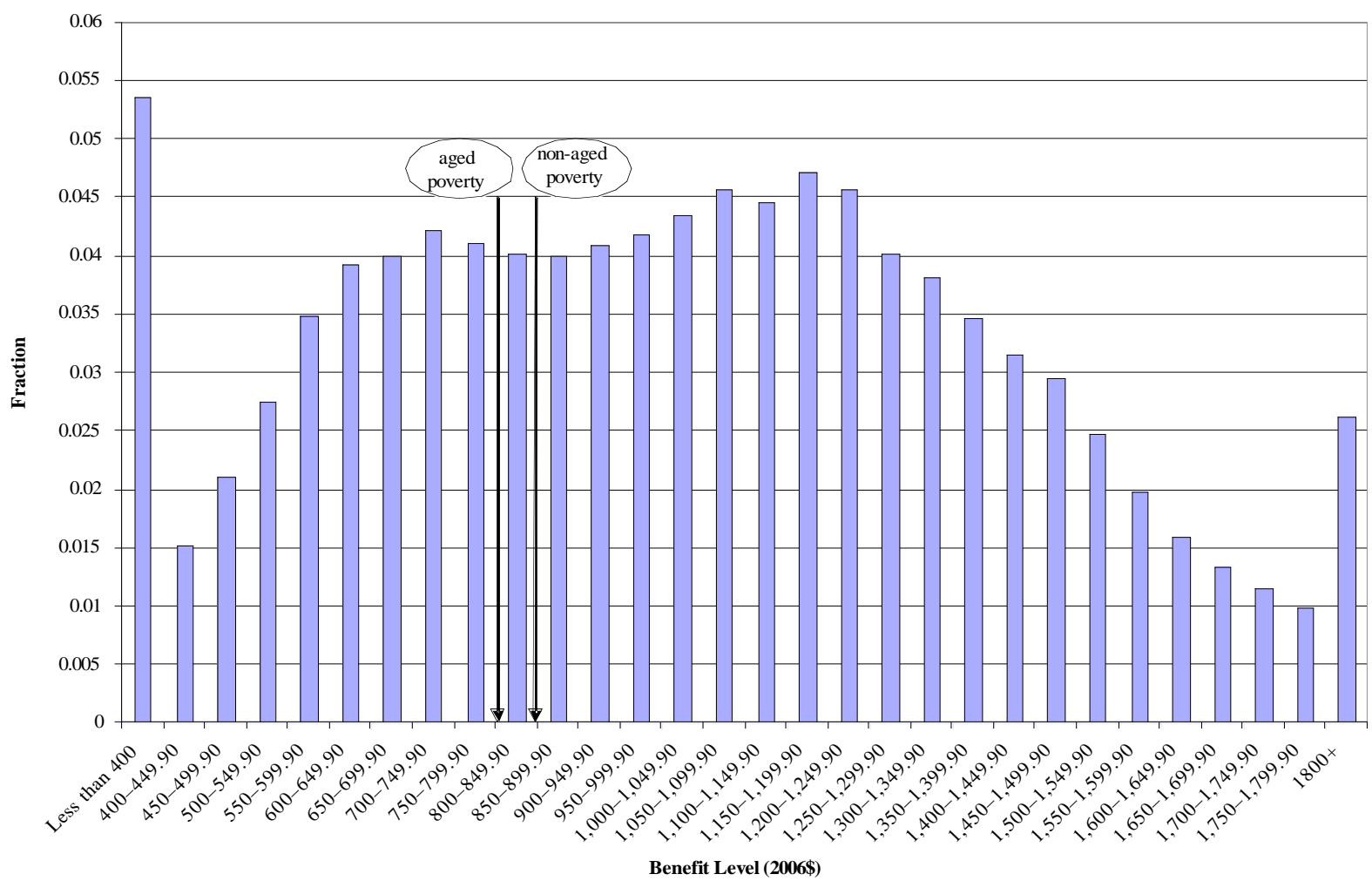

Source: Author's calculations from Social Security Administration (2008), Tables 5.B6, 5.D2, and 5.F11. Notes: Relationship between benefits and poverty thresholds assume that the monthly benefit for December is received for all 12 months of the year and that individuals live alone.

\footnotetext{
${ }^{14}$ These estimates include dual entitlees, those who are entitled to a worker benefit but receive a higher benefit as a spouse or survivor, but not those receiving spouse or survivor benefits only.

${ }^{15}$ Among all beneficiaries, these same figures were 85.6 and 92.3 percent, respectively.

${ }^{16}$ DYNASIM does not currently model children's benefits.
} 
The benefit distribution has several interesting features. First, there is a low tail of beneficiaries who receive benefits of less than $\$ 400$ per month. There is also a high tail of individuals receiving benefits of $\$ 1,800$ per month and above. In between, two peaks correspond roughly to the points where women's and men's worker benefits cluster. Compared to the earnings distribution, this benefit distribution is relatively flat. This reflects the Social Security benefit formula's progressivity, the fact that payroll tax contributions are capped at the taxable maximum and these higher earnings don't accrue additional benefits (thus reducing the influence of outliers), plus several other factors. These include, for example, 1.) the fact that benefits are based on the highest 35 years of earnings; 2.) beneficiaries' strong tendency to claim at the earliest possible age; ${ }^{17}$ and 3.) the fact that the Windfall Elimination Provision may affect some earners who receive pensions that they earned for work that was not covered by the Social Security system.

The two vertical lines in Figure 5 identify the location of poverty-level Social Security benefits, assuming that these individuals received benefits every month of 2006, using the aged poverty threshold (the line to the left) and the non-aged poverty threshold (the line to the right) for individuals. As evidenced by the substantial fraction of beneficiaries whose benefits fall to the left of these lines, a fair number of Social Security beneficiaries today-about 37.5 percent using a non-aged threshold and 31.5 percent using the aged threshold—do not receive a benefit that would on its own keep them out of poverty. These estimates of course represent an upper bound on poverty risk, given that many beneficiaries do not live alone, and over 80 percent have income from some other source (SSA 2006). Current estimates of beneficiary poverty reveal

\footnotetext{
${ }^{17}$ Less clustered claiming could lead to more dispersion in the distribution given actuarial reductions and delayed retirement credits that range from 70 percent of a benefit to 132.5 percent depending on birth cohort and claiming age.
} 
that about 9.9 percent of women and 4.8 percent of men remain in poverty after accounting for household size and other income sources (SSA 2006).

\section{Simulation results}

Before turning to the simulations about the different wage growth patterns, it is useful to first see how DYNASIM projects OASDI benefits to evolve under current law. Figure 6 shows how the adult Social Security benefit distribution evolves (for 2020 and 2040). (To facilitate comparisons, it uses the same benefit level breaks as Figure 5 and also expresses benefits in 2006 dollars.) Perhaps the most striking aspect of this figure is how much it differs from Figure 5. We see significant shifting of the benefit distribution to the right (i.e., toward higher benefit levels) over the 14/34 years. This corresponds to the assumed growth in real wages discussed earlier (and illustrated in Figure 2), plus other factors (e.g., increases in women's work histories, a declining share of those who worked when OASDI coverage rates were relatively low).

Figure 6. Social Security Benefit Distribution:

Retired and Disabled Workers and non-Disabled Widow(er)s, 2020 and 2040

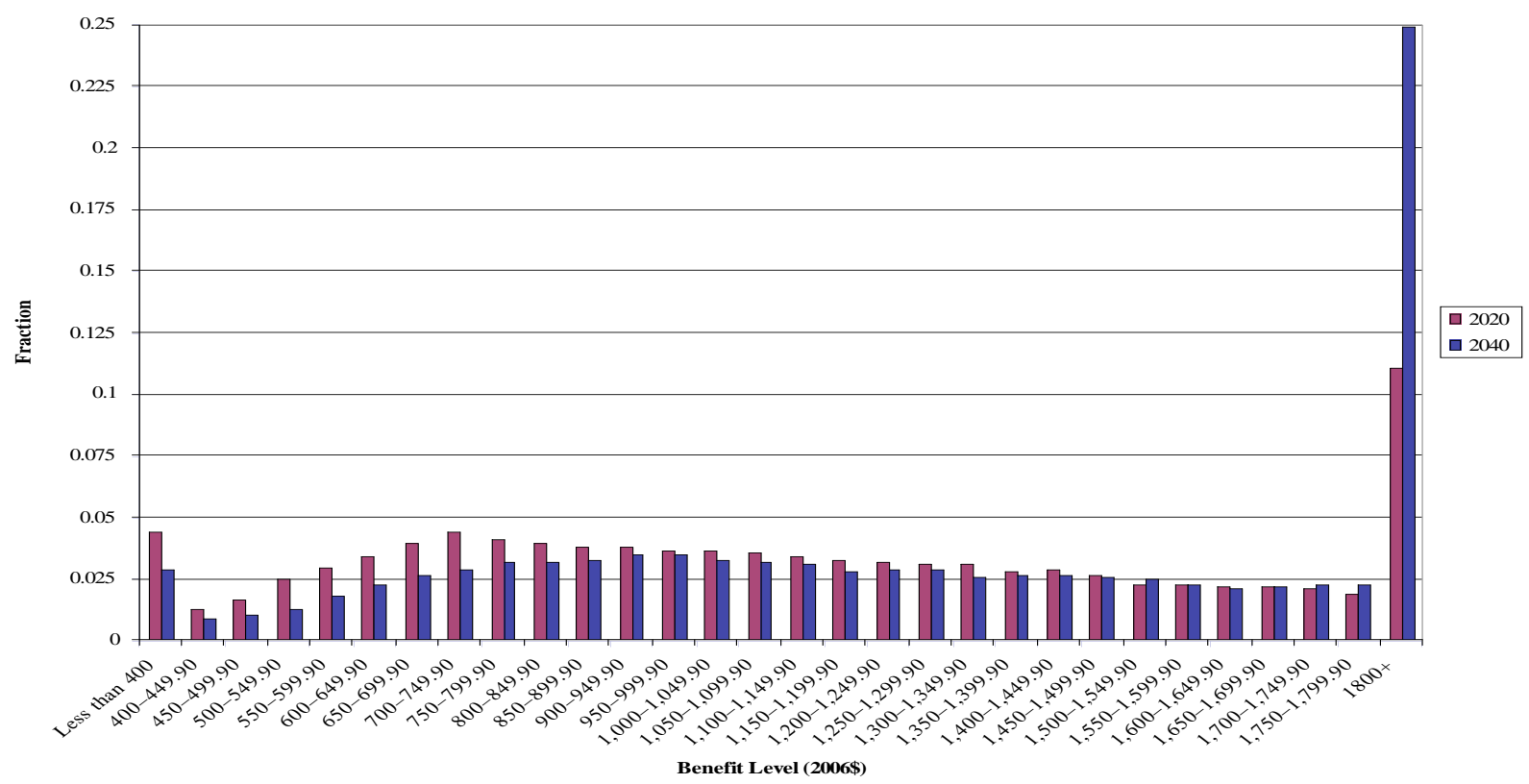

Source: Authors' calculations from DYNASIM3 (run id number 592). 
An important point to bear in mind is that starting in 2041, however, full scheduled Social Security benefits, as reflected in the projected 2040 distribution, will not be payable. Benefits could immediately decline by as much as 21 percent (less if Congress addresses Social Security's long-term financing problems partially through increased payroll tax contributions or some other revenue source). This would of course represent a marked shift back to the left in the distribution that would clearly offset many of the demonstrated effects of cumulative wage growth on benefits.

We next turn to the simulations under the alternative assumptions about wages. These results suggest that different wage growth patterns would have varied effects on a variety of outcomes, including the Social Security payroll tax and benefit distributions, and, it follows, the program's long-run fiscal position. However, given the modesty of the wage growth changes that we assume, these effects take a fairly long time to play out. The effects are most noticeable for those individuals for whom the wage change was in effect for all (or at least most) of their working lives. This means those who were in their late teens and early twenties (or younger) in 2009 when the simulation took effect, who will reach Social Security's early retirement age starting around 2050. We thus focus on results that are relatively late far into the forecasting period (2060 and 2070).

Specifically, we see markedly higher benefits at the lowest benefit percentiles under the simulation assuming greater wage growth at the middle and bottom of the distribution (Figures 7a and 7b). (These figures depict the Social Security benefit percentiles--again for retired and disabled workers and aged survivors--in two percentile increments, rather than real benefits.) When the wage growth is more concentrated at the top, the results reverse, though the difference from our best guess assumptions is much less striking. 
Figure 7a. Bottom Half of the Social Security Benefit Distribution under Alternative Wage Growth Assumptions: Retired and Disabled Workers and non-Disabled Widow(er)s, 2060

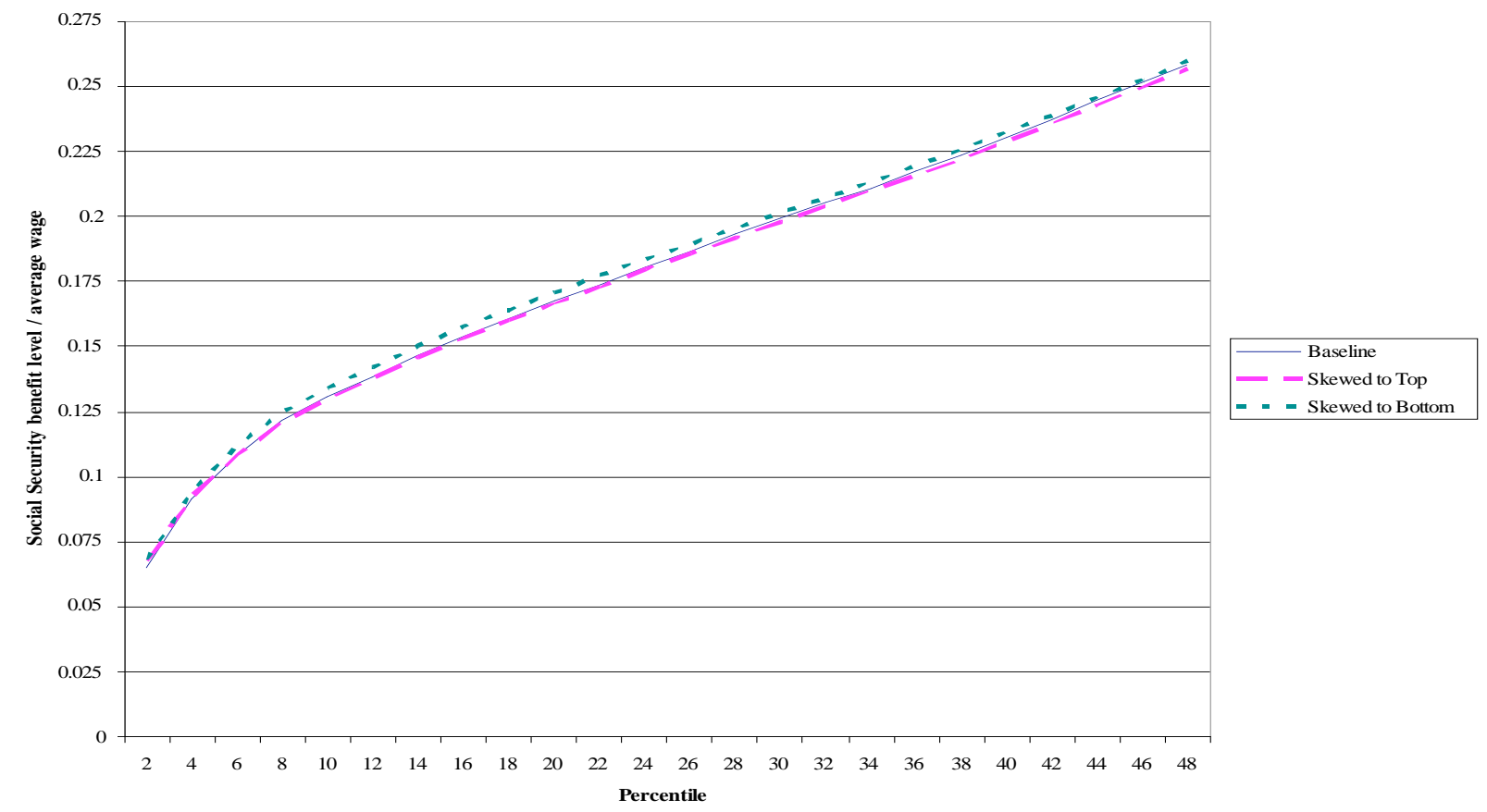

Source: Authors' calculations from DYNASIM3 (run id numbers 592, 598, and 600).

Notes: OASDI benefits presented are scheduled benefits.

Figure 7b. Bottom Half of the Social Security Benefit Distribution under Alternative Wage Growth Assumptions: Retired and Disabled Workers and non-Disabled Widow(er)s, 2070

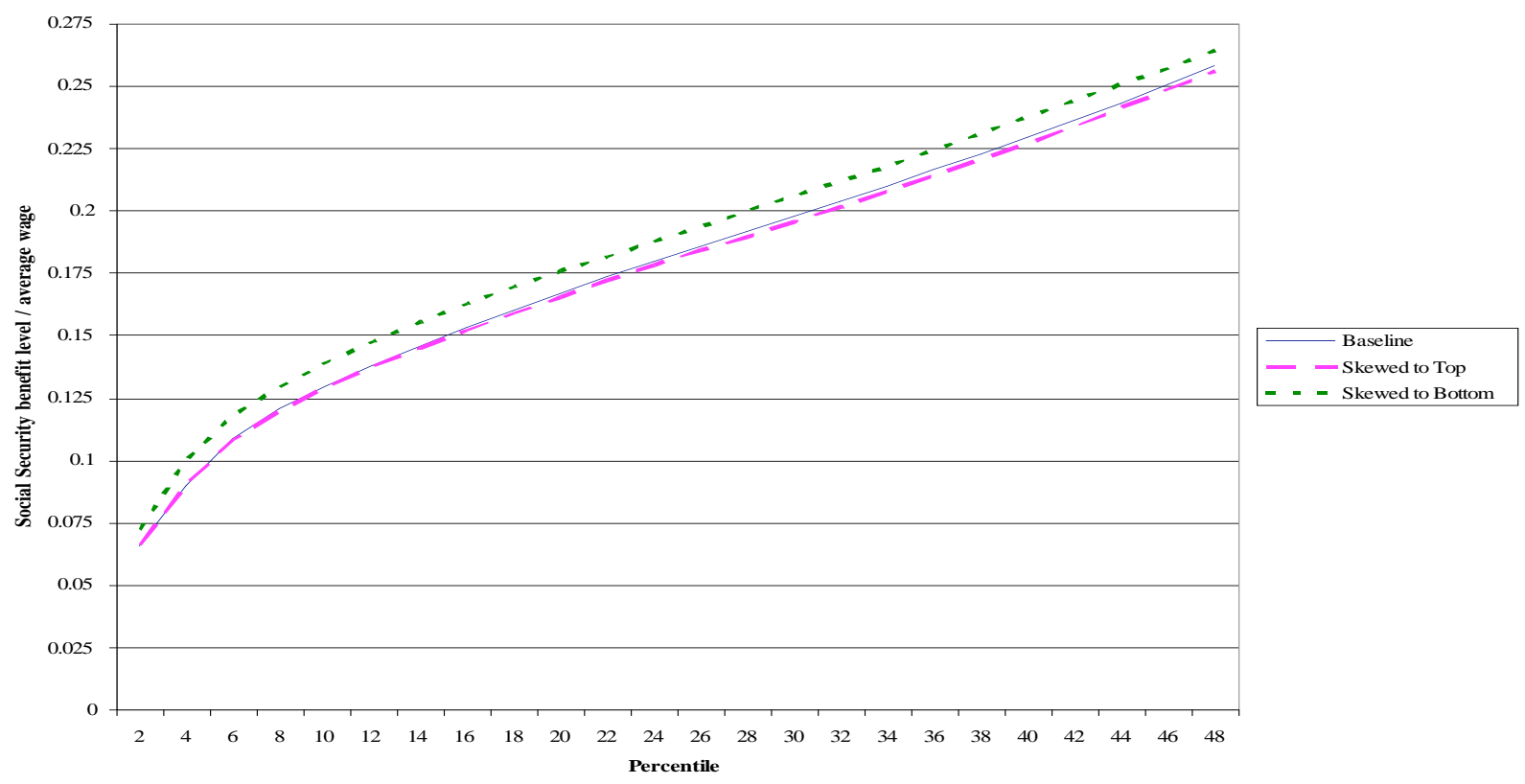

Source: Authors' calculations from DYNASIM3 (run id numbers 592, 598, and 600).

Notes: OASDI benefits presented are scheduled benefits. 
Poverty, correspondingly, declines relative to the baseline assumptions when the skew is toward lower and moderate wage earners but does not change under the option in which wage growth is more skewed toward higher earners (Table 2). Because we are examining years after 2040 (the last year that Social Security Actuaries project that the Trust Fund will be solvent), we present two separate poverty estimates: one based on scheduled Social Security benefits, and one based on payable Social Security benefits. The option with faster wage growth at the bottom reduces poverty in 2060 by about 0.4 percentage points for both the payable and scheduled projections. By 2070, its effects are larger, about a 0.5 percentage point reduction relative to current law scheduled and 0.8 percentage points relative to current law payable. These figures reflects approximately 593,000 and 949,000, individuals removed from poverty were scheduled and payable benefits available, respectively. Projections of changes to near poverty (defined as family earnings of less then 120 percent of the poverty threshold) differ modestly, but do not change the overall story.

Table 2. Poverty and Near-Poverty Status of Persons Ages 62 and Older plus Social Security Disabled Worker Beneficiaries under the Alternative Assumptions about Wage Growth in 2060 and 2070

\begin{tabular}{|c|c|c|c|c|c|c|c|c|}
\hline \multirow[t]{3}{*}{ Scenario } & \multicolumn{4}{|c|}{ Poverty (\%) } & \multicolumn{4}{|c|}{ Near Poverty (\%) } \\
\hline & \multicolumn{2}{|c|}{2060} & \multicolumn{2}{|c|}{2070} & \multicolumn{2}{|c|}{2060} & \multicolumn{2}{|c|}{2070} \\
\hline & $\begin{array}{c}\text { Sched- } \\
\text { uled }\end{array}$ & $\begin{array}{c}\text { Payable } \\
\end{array}$ & $\begin{array}{c}\text { Sched- } \\
\text { uled }\end{array}$ & Payable & $\begin{array}{l}\text { Sched- } \\
\text { uled }\end{array}$ & Payable & $\begin{array}{l}\text { Sched- } \\
\text { uled }\end{array}$ & Payable \\
\hline Baseline & 3.9 & 5.5 & 3.4 & 4.9 & 5.8 & 8.5 & 5.0 & 7.4 \\
\hline $\begin{array}{l}\text { Wage growth skewed } \\
\text { toward high-earners }\end{array}$ & 3.9 & 5.5 & 3.4 & 4.9 & 5.8 & 8.5 & 5.0 & 7.5 \\
\hline $\begin{array}{l}\text { Wage growth skewed } \\
\text { toward low- to } \\
\text { moderate-earners }\end{array}$ & 3.5 & 5.1 & 2.9 & 4.1 & 5.3 & 8.0 & 4.2 & 6.5 \\
\hline
\end{tabular}

Source: Authors' calculations from DYNASIM3 (run id numbers 592, 598, and 600).

Notes: Excludes non-aged spouse beneficiaries. OASDI benefit projections for 2060 are scheduled benefits. Calculations use aged poverty thresholds for both aged and disabled beneficiaries. Near poverty is defined as family income of less than 125 percent of the poverty threshold. 
Our simulation in which wage growth was skewed more toward high earners leads to a projected deterioration in Social Security's financing relative to the baseline, best guess assumptions, while the simulation in which growth is skewed toward lower and moderate earners made an improvement in long-term financing (Table 3). Our first measure of this is the change in the insolvency date for the OASDI Trust Fund, which predominantly reflects changes over the first 30 or so years this new assumption about wage growth is in place. DYNASIM projects a three-year improvement in the case in which wage growth is more skewed toward lower to moderate earners, while there is a one-year deterioration in the high-skew alternative.

\section{Table 3. Changes to Social Security Solvency (Relative to Current Law Scheduled) under the Alternative Assumptions about Wage Growth}

\begin{tabular}{lcc}
\hline \multicolumn{1}{c}{ Scenario } & $\begin{array}{c}\text { Change in year } \\
\text { of OASDI Trust } \\
\text { Fund insolvency }\end{array}$ & $\begin{array}{c}\text { Deficit in 74 } \\
\text { year (as a percent } \\
\text { of current law) }\end{array}$ \\
\hline Baseline & 0 & $100.0 \%$ \\
$\begin{array}{l}\text { Wage growth skewed toward high-wage } \\
\text { workers }\end{array}$ & -1 year & $110.5 \%$ \\
$\begin{array}{l}\text { Wage growth skewed toward moderate- } \\
\text { and low-wage workers }\end{array}$ & +3 years & $90.3 \%$ \\
\hline
\end{tabular}

Source: Authors' calculations from DYNASIM3 (run id numbers 592, 598, and 600).

Notes: DYNASIM projects only adult benefits, so we project children's benefits using assumptions based on recent percentages of total benefits that children's benefits have comprised.

Because the changes to Social Security benefits under these two scenarios are "backloaded" (i.e., they primarily occur after 2041, the year Social Security becomes insolvent), the change in the insolvency date is not a very comprehensive measure of the scenario's overall effects on system financing. Table 3 thus also presents a separate measure, the change in the overall (cumulative) Social Security deficit in the $74^{\text {th }}$ year of the simulation horizon (2082). 
Under the scenario with wage growth skewed toward the top, this deteriorates by about 10.5 percent, while with the skew toward lower- and moderate-wage workers improves the financing situation by about 9.7 percent.

\section{Caveats}

These projection analyses are quite simple and stylized. Differential wage growth could affect earners and the earnings distribution in an infinite number of ways, even when assuming the same fraction of total OASDI earnings subject to payroll tax. We have considered just two simplistic alternatives, which show how subtle differences in the way wage growth is distributed across alternatives could influence the results.

Although the changes to benefit and income distributions and long-range position of the Social Security Trust Fund in the results are modest, the range of possible alternatives that we have simulated is actually quite narrow. In none of the simulations does the fraction of earnings assumed to fall below the taxable maximum over the long-run even approach the levels that we observed as little as a decade ago. In all three cases, we are assuming a continuation in a "polarized" wage distribution.

Another important caveat concerns the period of analysis. Our analyses are limited to a

75 -year projection horizon. Differences between the scenarios in what happens in the $75^{\text {th }}$ or $76^{\text {th }}$ year can add critical information about the sustainability of the program under alternative analyses.

\section{Conclusions and policy implications}

The U.S economy is a complex, continually evolving system. One change that has received a lot of attention in recent years is the increased concentration of total earnings among 
the highest earners, a trend that few analysts expect to reverse and that many anticipate will continue.

This paper has used a dynamic microsimulation model to describe how different assumptions about the future shape of the earnings distribution—and particularly its skewnesscould affect Social Security solvency and the outcomes of individual beneficiaries. Our stylized analyses suggest that highly skewed wage growth at the top of the distribution could lead to deterioration in Social Security finances. Wage growth that is more directed at the bottom and lower-middle could, in contrast, shore up the system's finances and have the additional effect of reducing poverty and near poverty. While we did not simulate this, it follows that wage growth that was more skewed toward the middle (or particularly the "higher middle") could likely improve Social Security’s long-term prospects.

Consistent with the observations of the Technical Panel (2007), we conclude that this question deserves further research along a broader range of assumptions about how precisely skewness in the income distribution is being generated. We have used two very simplistic assumptions that focus on individual-specific aspects of wage growth, but the implications for Social Security and income distribution likely differ in important ways based on the characteristics of the assumed changes to the underlying earnings process (e.g., returns to education as opposed to idiosyncratic or transitory factors).

Government's ability to play a role in shaping larger trends in the way that the labor market rewards education and talent is likely relatively modest. ${ }^{18}$ Government can, however, clearly play a greater role in shaping the distribution of post-tax, post-transfer incomes. Because

\footnotetext{
${ }^{18}$ Policies like the federal minimum wage play some role, though in recent years state minimum wages have often exceeded the federal minimum wage. Current discussions of economic stimulus make it clear that investments must be very large in order to have a large impact.
} 
so many Americans pay far more in payroll taxes than they do in federal personal income taxes (Tax Policy Center 2008), the level of the Social Security contribution and benefit base should be considered when crafting any tax reform and considering ways to shore up the program's longterm finances. More broadly, trends in the wage distribution must also be factored into a wide range of policy choices about taxes and savings incentives. Individuals' abilities to save in order to finance a secure retirement depend to a considerable degree on larger economic trends, like wage polarization, over which they have limited control. If wages at the bottom of the distribution continue to languish, significant fractions of the aged beneficiary population could remain vulnerable to poverty despite increased prosperity for the population as a whole, especially given Social Security's underfunding. 


\section{References:}

Autor, David H., Lawrence F. Katz, and Melissa S. Kearney. 2006. "The Polarization of the U.S. Labor Market." American Economic Review Papers and Proceedings 96: 189-194. . 2008. "Trends in U.S. Wage Inequality: Revising the Revisionists." Review of Economics and Statistics 90(2): 300-323.

Babington, Charles. 2008. “Obama wants payroll tax on incomes above $\$ 250,000$." Associated Press story, dated June 13, available at: http://news.yahoo.com/s/ap/20080613/ap_on_el_pr/obama_social_security;_ylt=Avsm_v pbySAqzhbLEEccGFas0NUE.

Bernanke, Ben S. 2007. "The Level and Distribution of Economic Well-Being." Remarks before the Greater Omaha Chamber of Commerce.

Blau, Francine D. and Lawrence M. Kahn. 2007. "Changes in the Labor Supply Behavior of Married Women: 1980-2000." Journal of Labor Economics 25(3): 393-438.

Bush, George. 2007. Speech on State of the Economy Report, Delivered January 31, Federal Hall, New York, NY. Transcript available at: http://www.whitehouse.gov/news/releases/2007/01/20070131-1.html.

Committee on Ways and Means, United States House of Representatives. 2004. Overview of Entitlement Programs: 2004 Green Book Background Material and Data on Programs Within the Jurisdiction of the Committee on Ways and Means. Washington, DC: U.S. Government Printing Office.

Diamond, Peter A., and Peter R. Orszag. 2004. Saving Social Security: A Balanced Approach. Washington, DC: Brookings Institution Press. Summary available at: http://www.brookings.edu/views/papers/orszag/200504security.pdf.

Favreault, Melissa M. and Karen E. Smith. 2004. "A Primer on the Dynamic Simulation of Income Model (DYNASIM3)." Discussion Paper, the Retirement Project, Urban Institute. Available at: http://www.urban.org/UploadedPDF/410961 Dynasim3Primer.pdf.

Freeman, Richard B. 2001. “The Rising Tide Lifts...?” Pp. 97-126 in S. H. Danziger and R. H. Haveman, eds. Understanding Poverty. New York: Russell Sage Foundation and Harvard University Press.

Freking, Kevin. 2008. "Biden Set to Oversee Task Force on Strengthening Middle Class: Panel would Review Policies and Make Recommendations." Washington Post, December 22, p. A02. Available at: http://www.washingtonpost.com/wpdyn/content/article/2008/12/21/AR2008122102069.html. 
Goldin, Claudia and Lawrence F. Katz. 2007. "Long-Run Changes in the U.S. Wage Structure: Narrowing, Widening, Polarizing." NBER Working Paper 13568. Cambridge: NBER.

Gordon, Robert and Ian Dew-Becker. 2007. "Unresolved Issues in the Rise of American Inequality." Available at: http://www.people.fas.harvard.edu/ idew/papers/BPEA_final_ineq.pdf.

Gross, Daniel. 2007. "Why are Billionaires Fretting Over Income Inequality." Slate. Posted January 19. Available at: http://www.slate.com/id/2157859/.

Kopczuk, Wojciech, Emmanuel Saez, and Jae Song. 2007. "Uncovering the American Dream: Inequality and Mobility in Social Security Earnings Data since 1937.” Working Paper. Columbia University, the National Bureau of Economic Research, and the Social Security Administration.

Levy, Frank S. and Peter Temin. 2007. "Inequality and Institutions in $20^{\text {th }}$ Century America." Massachusetts Institute of Technology Department of Economics. Working Paper 07-17. Cambridge, MA.

Liebman, Jeffrey, Maya MacGuineas, and Andrew Samwick. 2005. "Nonpartisan Social Security Reform Plan." Available at: http://www.ksg.harvard.edu/jeffreyliebman/lms nonpartisan plan description.pdf.

Lillard, Lee and Robert Willis. 1978. "Dynamic Aspects of Earning Mobility," Econometrica, 46(5): 985 - 1012, September.

Machin, Stephen. 2008. "An Appraisal of Economic Research on Changes in Wage Inequality." Labour 22(Special Issue): 7-26.

Moffitt, Robert and Peter Gottschalk. 2002. "Trends in the Transitory Variance of Earnings in the United States," The Economic Journal, 112: C68 - C73.

OASDI Board of Trustees. 2008. 2008 Annual Report of the Board of Trustees of the Federal Old-Age and Survivors Insurance and Disability Insurance Trust Funds. Washington, DC: Author. Available at: http://www.ssa.gov/OACT/TR/TR08/.

Obama for America. 2008. "Seniors and Social Security: Plan to Strengthen Retirement Security." Available at: http://www.barackobama.com/issues/seniors/.

Pattison, David. 2003. "Labor Force Trends and Future Social Security Benefits." Available at: http://papers.ssrn.com/sol3/papers.cfm?abstract_id=390644.

Paulson, Henry. 2006. Remarks Delivered at Columbia University Business School. August 1. Available at: http://www.treasury.gov/press/releases/hp41.htm. 
Penner, Rudolph. 2008. "Can Faster Economic Growth Bail Out our Retirement Programs?" Retirement Policy Program Brief Series, Number 20. Washington, DC: Urban Institute. Available at: http://www.urban.org/UploadedPDF/411634 Growth Retirement.pdf.

Piketty, Thomas and Emmanuel Saez. 2003. "Income Inequality in the United States, 19131998." Quarterly Journal of Economics 118(1): 1-39.

. 2006. "The Evolution of Top Incomes: A Historical and International Perspective." American Economic Review Papers and Proceedings 96(2): 200-205.

Social Security Administration. 2006. Income of the Population 55 or Older, 2004. Office of Policy. Washington, DC: Author.

2008. Annual Statistical Supplement, 2007 the Social Security Bulletin. Washington, DC: Author. Available at:

http://www.socialsecurity.gov/policy/docs/statcomps/supplement/2007/index.html.

Tax Policy Center. 2008. Distribution of Federal Payroll and Income Taxes by Cash Income Class (Table T07-0115). Washington, DC: The Urban Institute. Available at: http://www.taxpolicycenter.org/numbers/displayatab.cfm?DocID=1517.

Technical Panel on Assumptions and Methods. 2007. Report to the Social Security Advisory Board. October. Available at:

http://www.socialsecurityadvisoryboard.gov/documents/2007_Technical_Panel_Report.P DF.

Wade, Alice H., J. Patrick Skirvin, and William M. Piet. 2005. "Computing the Ratio of Social Security Taxable Earnings to Covered Earnings; Implications for Provisions to Raise the Contribution and Benefit Base-Information." Social Security Administration. Available at: http://www.ssab.gov/documents/Taxable-Ratio-Computations-092905.pdf. 


\section{APPENDIX}

To examine how Social Security taxes and benefits play out with different wage growth patterns, Appendix Table 1 provides a qualitative evaluation of the relative effects of various types of earnings on the Social Security Trust Fund. ${ }^{19}$ The table considers the simple case in which a single individual is going to earn more at a point in time.

\section{Appendix Table 1. Relative Effects of Earnings at Various Points of the Lifetime Earnings Distribution on Social Security Solvency}

\begin{tabular}{|c|c|c|c|c|}
\hline & Characteristics of the earner/earnings & $\begin{array}{l}\text { Effect on } \\
\text { Payroll } \\
\text { Tax } \\
\text { Revenues }\end{array}$ & $\begin{array}{l}\text { Effect on } \\
\text { Benefit } \\
\text { Payments }\end{array}$ & $\begin{array}{l}\text { Net Effect } \\
\text { On } \\
\text { Solvency }\end{array}$ \\
\hline 1 & $\begin{array}{l}\text { Earned by worker who never attains insured } \\
\text { status (for any reason, including low levels of } \\
\text { work effort or emigration) or who dies (without } \\
\text { eligible survivors) before receiving benefits }\end{array}$ & + & 0 & + \\
\hline 2 & Earnings over the taxable maximum & 0 & 0 & 0 \\
\hline 3 & $\begin{array}{l}\text { Earnings below the first bend point among } \\
\text { insured workers }\end{array}$ & + & --- & $?$ \\
\hline 4 & $\begin{array}{l}\text { Earnings between first and second bend points } \\
\text { among insured workers }\end{array}$ & + & -- & $?$ \\
\hline 5 & $\begin{array}{l}\text { Earnings above second bend point but below } \\
\text { taxable maximum among insured workers }\end{array}$ & + & - & $?$ \\
\hline 6 & $\begin{array}{l}\text { Earnings of married people with non-working } \\
\text { spouse }\end{array}$ & + & - & $?$ \\
\hline 7 & $\begin{array}{l}\text { Earnings by worker who qualifies for a higher } \\
\text { benefit as a spouse, and will continue to qualify } \\
\text { as a spouse after the added earnings }\end{array}$ & + & 0 & + \\
\hline
\end{tabular}

Notes: "+" indicates a positive effect; "-" indicates a negative effect; "?" indicates that the effect cannot be determined without additional information; all assessments are made before assuming zero sum game (i.e., that someone loses wages for someone else's gains). ${ }^{20}$

\footnotetext{
${ }^{19}$ This list presents several stylized, illustrative examples rather than a comprehensive catalog of earnings types.

${ }^{20}$ In the real world, evaluations are far more complicated. Jobs are continually being created and lost. Some people receive large raises while others take hours or wage cuts. Individuals often move across various points in the wage distribution throughout their lifetimes, and they move in and out of families with varying levels of resources.
} 
From the Trust Fund perspective, the most advantageous earnings are those that generate payroll taxes but that will not result in any additional benefit payments. These would include, for example, earnings from a worker who never marries and who has fewer than 35 covered quarters of earnings. Least advantageous are those earnings that will later generate large benefits but relatively low payroll tax revenues (for example, earnings by a low-earner with a short career that just exceeds the 40 covered quarters threshold who is married to a non-worker). Earnings over the taxable maximum fall in between these two extremes: while they do not improve the Trust Fund situation by adding revenue to the system, they also do not add any more liabilities, given that the earnings over this threshold do not contribute to higher benefits (hence the more formal term for the taxable maximum, the OASDI "contribution and benefit base").

With additional wages, most earners will generate payroll tax revenues while also accruing future benefit claims, with the relative cost to the system depending on where their lifetime earnings fall in relation to the formula brackets. Generally speaking, in this intermediate range, the Trust Fund is better off when moderate to high lifetime earners (who are in the 15 percent replacement bracket) earn more, rather than when moderate earners (in the 32 percent bracket) or, especially, low earners (in the 90 percent bracket) earn more.

The relative rankings of different earnings patterns change when we consider the effects of these additional earnings from another perspective: the effect on old-age or beneficiary poverty. Earnings to those in the lowest brackets, as long as the worker has exceeded coverage levels required for insured status, are most likely to reduce poverty or near poverty. Earnings that generate no benefit entitlement likely have minimal effect on beneficiary poverty (since relatively small shares of workers are Social Security beneficiaries). 


\section{RECENT WORKING PAPERS FROM THE}

\section{CENTER FOR RETIREMENT RESEARCH AT BOSTON COLLEGE}

Accounting for the Heterogeneity in Retirement Wealth

Fang Yang, January 2009

Labor Supply Elasticity and Social Security Reform

Selahattin Imrohorolu and Sagiri Kitao, January 2009

Evaluating Micro-Survey Estimates of Wealth and Saving

Barry P. Bosworth and Rosanna Smart, January 2009

Portfolio Choice in Retirement: Health Risk and the Demand for Annuities, Housing, and Risky Assets

Motohiro Yogo, January 2009

The Disappearing Defined Benefit Pension and its Potential Impact on the Retirement Incomes of Boomers

Barbara A. Butrica, Howard M. Iams, Karen E. Smith, and Eric J. Toder, January 2009

Retirement and Social Security: A Time Series Approach

Brendan Cushing-Daniels and C. Eugene Steuerle, January 2009

Economic Restructuring and Retirement in Urban China

John Giles, January 2009

Sources of Support for Pension Reform: A Cross-National Perspective

Michelle Dion and Andrew Roberts, January 2009

The Long-Term Effect of the Divorce Revolution: Health, Wealth, and Labor

Supply

Kristin Mammen, December 2008

The Response of Household Saving to the Large Shock of German Reunification Nicola Fuchs-Schündeln, November 2008

A Parsimonious Choquet Model of Subjective Life Expectancy

Alexander Ludwig and Alexander Zimper, November 2008

Risky Pensions and Household Saving Over the Life Cycle

David A. Love and Paul A. Smith, November 2008 